\title{
Biomass for energy in the European Union - a review of bioenergy resource assessments
}

\author{
Niclas Scott Bentsen ${ }^{*}$ and Claus Felby
}

\begin{abstract}
This paper reviews recent literature on bioenergy potentials in conjunction with available biomass conversion technologies. The geographical scope is the European Union, which has set a course for long term development of its energy supply from the current dependence on fossil resources to a dominance of renewable resources. A cornerstone in European energy policies and strategies is biomass and bioenergy. The annual demand for biomass for energy is estimated to increase from the current level of $5.7 \mathrm{EJ}$ to $10.0 \mathrm{EJ}$ in 2020. Assessments of bioenergy potentials vary substantially due to methodological inconsistency and assumptions applied by individual authors. Forest biomass, agricultural residues and energy crops constitute the three major sources of biomass for energy, with the latter probably developing into the most important source over the $21^{\text {st }}$ century. Land use and the changes thereof is a key issue in sustainable bioenergy production as land availability is an ultimately limiting factor.
\end{abstract}

Keywords: Bioenergy, Biomass resource potential, Land use

\section{Introduction}

Energy security and climate change mitigation are core elements in current European energy policy. The EU countries are mandated to meet by 2020 a target of $20 \%$ renewable resources in the energy supply and $10 \%$ renewable resources in energy in the transport sector [1]. The latter corresponds to a replacement of 50 billion litres of fossil transportation fuels. The Energy Strategy 2020 [2] of the European Commission calls for increased use of renewable resources in the energy system and the European Council has presented a long term target for the EU and other industrialised countries of 80 to $95 \%$ cuts in greenhouse gas emissions by 2050. A cornerstone in renewable energy projections of the European Union is biomass, which is expected to account for $56 \%$ of the renewable energy supply in the EU27 ${ }^{\mathrm{a}}$ by 2020 (Figure 1).

Government programmes towards increased use of renewable resources for energy are not exclusive to Europe. In the United States the Energy Policy Act [3] and the Energy Independence and Security Act [4] focus on promoting various renewable resources, wind, solar, hydro, geothermal and within biomass mainly liquid biofuels and sets a target of 136 billion litres of biofuel for transport in

\footnotetext{
* Correspondence: nb@life.ku.dk

Faculty of Life Sciences, University of Copenhagen, Rolighedsvej 23, Copenhagen, DK-1958Frederiksberg, Denmark
}

2022, hereof 80 billion litres from advanced biofuels, not based on corn starch. The Brazilian ProAlcool programme from 1975 [5] has contributed to an increased Brazilian ethanol production from below 1 billion litres in 1975 to 26 billion litres in 2009/10 [6-8].

The global perspectives for future energy production are on the use of more renewable resources in general and on biomass in particular [9]. In the European Union the overall target for renewable energy is higher than anywhere else.

\section{Biomass supply for energy in the EU}

Numerous studies on biomass/bioenergy resources on global [10-36] and European [16,18,23,30,37-56] level have been published over the last 20 years. This review concerns European bioenergy resources only. For comprehensive reviews on global bioenergy levels Berndes et al. [57] and Offermann et al. [58] may be consulted. In the following we summarize estimates of biomass for bioenergy resources on a European level (Table 1). The geographical coverage is the EU25, EU27 or geographical Europe excluding former Soviet states. The impact of various geographical scopes is discussed in the subsequent section. All resource potentials are expressed as lower heating value of the primary biomass. 


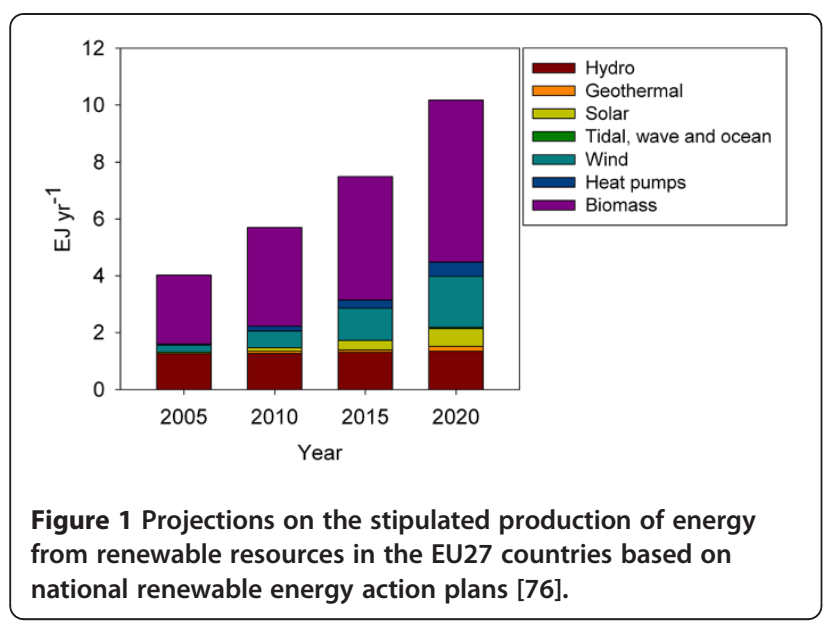

Dedicated energy crops are expected to make up a major part of future bioenergy supplies (Figure 2a). Estimates of the current $(2010)$ resource range from 0.82.0 $\mathrm{EJyr}^{-1}$, increasing to $4.3-6.0 \mathrm{EJyr}^{-1}$ in $2030,3-56$
$\mathrm{EJyr}^{-1}$ in 2050 and $22-34 \mathrm{EJyr}^{-1}$ by the end of this century. The overall increasing trend is supported by individual resource estimates over time (Figure 3).

Residues from agricultural production e.g. cereal straw, corn stover and rape straw is a readily available resource from already managed land. Estimates of the current resource range from 0.8 to $3.9 \mathrm{EJyr}^{-1}$ (Figure 2b). There is no unambiguous trend in estimates towards increasing or decreasing resources in the future. 2030 estimates range from 0.9 to $3.1 \mathrm{EJyr}^{-1}$ and 2050 estimates range from 0.6 to $5.0 \mathrm{EJyr}^{-1}$.

Forest biomass constitutes felling residues and wood biomass from early thinning and stand management. The current forest bioenergy potential shows the largest variation, with estimates between 0.8 and $6.0 \mathrm{EJyr}^{-1}$ (Figure 2c). 2050 estimates range from 0.8 to $10.6 \mathrm{EJyr}^{-1}$. The EU27 countries also have potential biomass resources from already processed biomass. These resources are highly diverse and constitute e.g. sewage sludge, municipal solid waste, wood processing residues, manure, other agricultural

Table 1 Characteristics of studies included in the summary of European bioenergy potentials

\begin{tabular}{|c|c|c|c|c|c|c|}
\hline Reference & $\begin{array}{l}\text { Year of } \\
\text { publication }\end{array}$ & $\begin{array}{l}\text { Type of } \\
\text { publicationt }\end{array}$ & Biomass resources $:$ & $\begin{array}{l}\text { Type } \\
\text { of potential \# }\end{array}$ & Temporal scope & $\begin{array}{l}\text { Geographical } \\
\text { scope }\end{array}$ \\
\hline Asikainen [59] & 2008 & Report & $\mathrm{FO}$ & Theoretical + technical & 2000-10 & EU27 \\
\hline Böttcher [39] & 2010 & Report & $A R, F O$ & Theoretical + technical & 2010 & EU27 \\
\hline Ericsson [41] & 2006 & Journal & $\mathrm{EC}, \mathrm{AR}, \mathrm{FO}$ & Technical & $\begin{array}{l}2015-25,2025-45, \\
2045-\end{array}$ & EU25 \\
\hline Fischer [16] & 2001 & Journal & $E C, A R$ & Technical-sustainable & 1990,2050 & $\begin{array}{l}\mathrm{EU} 27+(\mathrm{CH}, \\
\mathrm{NO}, \mathrm{IS} \text { and } \\
\text { Balkan), } \\
\text {-(Baltic states) }\end{array}$ \\
\hline Fischer [44] & 2010 & Journal & $A R$ & Technical-sustainable & 2000,2030 & EU27 \\
\hline Haberl [18] & 2010 & Journal & $E C, A R, F O$ & Technical-sustainable & 2050 & $\begin{array}{l}\text { Geographical } \\
\text { Europe -(former Soviet } \\
\text { states) }\end{array}$ \\
\hline Hoogwijk [23] & 2005 & Journal & EC & Technical & 2050,2100 & $\begin{array}{l}\mathrm{EU} 27+(\mathrm{CH}, \\
\mathrm{NO}, \mathrm{IS} \text { and Balkan), } \\
\text {-(Baltic states) }\end{array}$ \\
\hline Mantau [60] & & Report & $\mathrm{FO}$ & Theoretical + technical & $2010,2020,2030$ & EU27 \\
\hline Panoustou [56] & 2009 & Journal & $A R, F O$ & Technical & 2000, 2010, 2020 & EU27 \\
\hline RENEW [53] & 2008 & Report & $E C, A R, F O$ & Technical & 2000-09, 2020 & $\begin{array}{l}\mathrm{EU} 27+\mathrm{CH}, \\
-(\mathrm{CY}, \mathrm{MT})\end{array}$ \\
\hline Scarlat [49] & 2010 & Journal & $A R$ & Technical-sustainable & & EU25 \\
\hline Siemons [50] & 2004 & Report & $\mathrm{EC}, \mathrm{AR}, \mathrm{FO}$ & Technical-economic & $2000,2010,2020$ & EU27 \\
\hline Smeets [30] & 2007 & Journal & $E C, A R$ & Technical & 2050 & $\begin{array}{l}\mathrm{EU} 27+(\mathrm{CH}, \\
\mathrm{NO}, \mathrm{IS} \text { and Balkan), } \\
\text {-(Baltic states) }\end{array}$ \\
\hline Panoustou [56] & 2009 & Journal & $A R, F O$ & Technical-economic & $2000,2010,2020$ & EU27 \\
\hline Smeets [31] & 2007 & Journal & $\mathrm{FO}$ & Technical & 2050 & $\begin{array}{l}\mathrm{EU} 27+(\mathrm{CH} \\
\mathrm{NO}, \mathrm{IS} \text { and Balkan), }\end{array}$ \\
\hline Van Vuren [35] & 2009 & Journal & $\mathrm{FO}$ & Technical-economic & 2050 & $\begin{array}{l}\mathrm{EU} 27+(\mathrm{CH} \\
\text { NO, IS and Balkan) }\end{array}$ \\
\hline
\end{tabular}

† 'Report': Data published in a report. 'Journal': Data published in refereed journals.

$+{ }^{\prime} E C^{\prime}=$ dedicated energy crops,'AR' = agricultural residues, ' $F O^{\prime}=$ forest biomass.

\# The distinction between different types of biomass resource potentials is explained below; ' $+^{\prime}=$ two different resource potentials are estimated, ' $-'=$ type of resource potential cannot be assigned one category. 

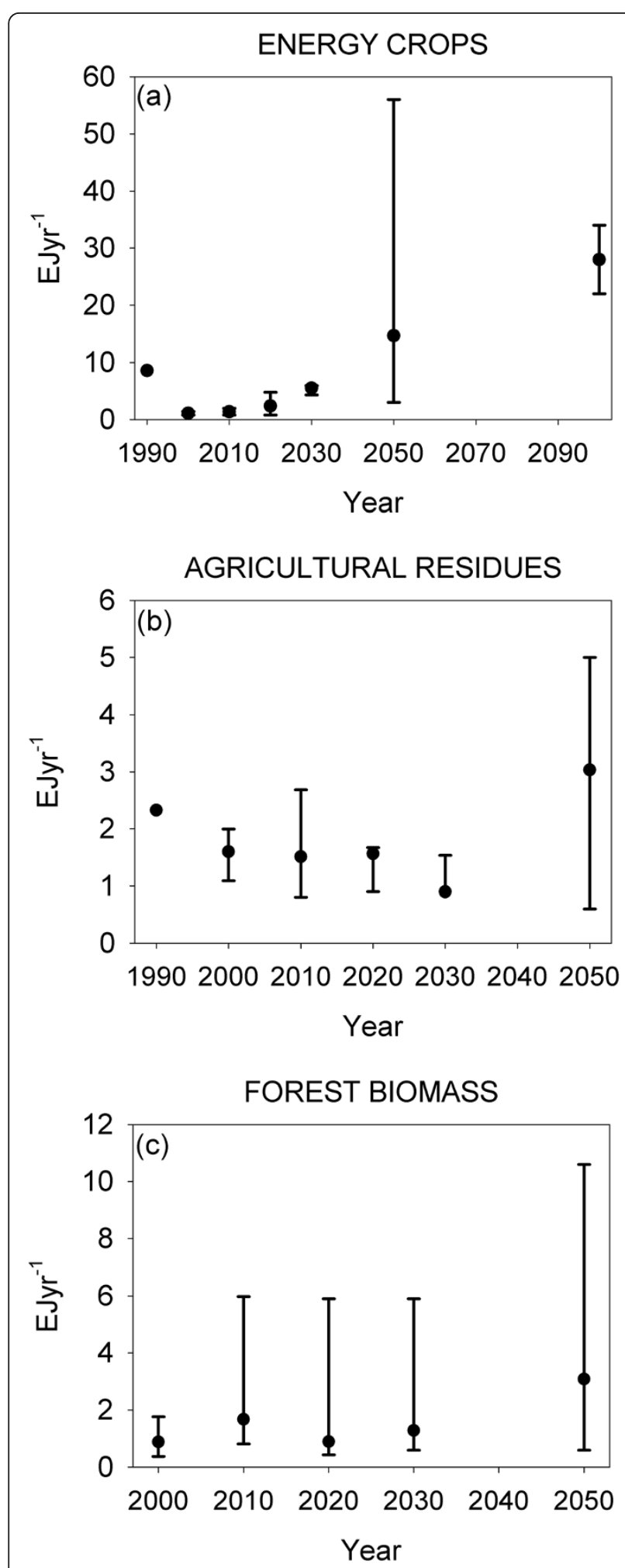

Figure 2 Median and range of the potential from three major sources of biomass for energy. Data on energy crops are based on $[16,18,23,30,41,50,53,54]$, agricultural residues based on $[16,18,30,39,41,44,49,50,53,55,56]$, and forest biomass based on $[18,31,35,39,41,50,53,54,56,59,60]$.

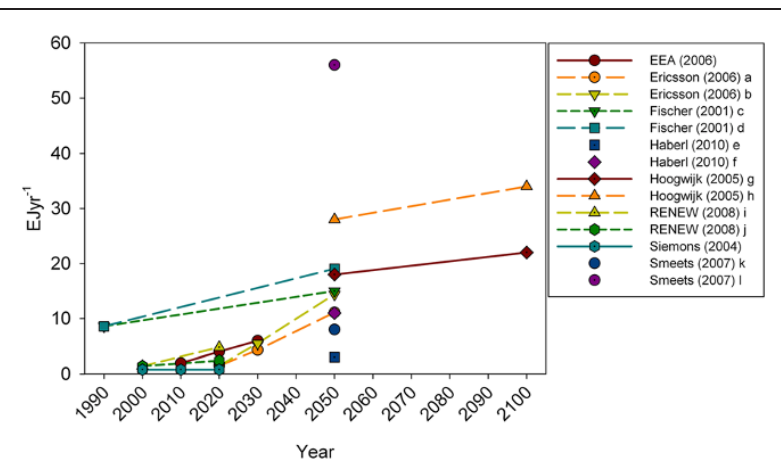

Figure 3 EU25/27 Energy crop potential from 1990 to 2100 from individual studies. Letters a-f signifies different scenarios. a low biomass harvest; $b$ - high biomass harvest; $c$ - min; $d$ - max; e Scenario S1, maximised biofuel production by 2020; f - Scenario S2, self-sufficient biofuel production by 2020.

wastes, and food processing waste. The European Environmental Agency (EEA) assesses the secondary biomass resources to $3.1 \mathrm{EJyr}^{-1}$ in 2010 , growing to 3.2 $\mathrm{EJyr}^{-1}$ in 2030. Focussing on wood industry residues Ericsson et al. [41] assess the resource for the EU25 to 1.1 $E \mathrm{Jyr}^{-1}$ from 2020 past 2040, Mantau et al. [60] find an EU27 potential of $1.0 \mathrm{EJyr}^{-1}$ in 2010 and $1.3 \mathrm{EJyr}^{-1}$ in 2030. In comparison the EEA [42] assessment of wood processing residues find an EU25 potential of only $\sim 0.4 \mathrm{EJyr}^{-1}$.

\section{Discussion}

\section{Energy crops}

Currently energy crops in Europe comprise mainly traditional food crops as rape seed and sugar or starch crops [61]. In future supply scenarios lignocellulosic energy crops are expected to play a larger role. de Witt et al. [54] finds that the potential from traditional food crops will increase with $7.3 \mathrm{EJyr}^{-1}$ from 2010 to 2030, whereas the potential from lignocellulosic crops will increase with $15.3 \mathrm{EJyr}^{-1}$ (Figure 4).

\section{Agricultural residues}

Agriculture in the EU27 countries is characterised by a high proportion of cereal production. In $200756 \%$ of arable lands were grown with cereals [62]. Thus agricultural residues comprise mainly straw, leaves and stalks from grass species (Poaceae family) as e.g. wheat, maize, barley and rye.

\section{Forest biomass}

The EU27 countries have experienced a steady increase in wooded land of more than 22 Million ha over the past more than 20 years [63] and resources from forestry and forest industries are a main contribution to bioenergy production. At present forest biomass is mainly used to 


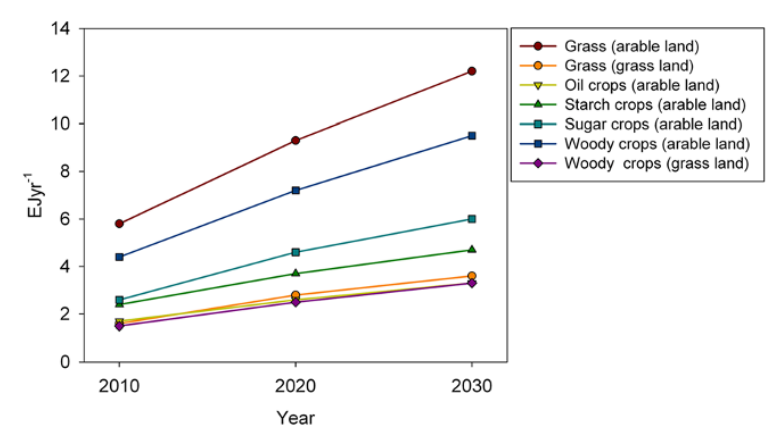

Figure 4 Development in the potential of different dedicated energy crops from 2010 to 2030 on arable land or grass lands respectively. Data from [54].

support material demand, however, between 2010 and 2020 energy purposes may take over as the major demand [60]. The potential supply of biomass from forests, stems, felling residues and bark is not expected to change significantly from 2010 to 2030, but the potential from wood industry residues will increase some $30 \%$ in the same period [60].

\section{Development trends}

Many of the reviewed studies point to short rotation (110 years) energy crops as the main future resource of biomass for energy purposes. A reason for this probably relates to the fact that such crops fit in the current EU Common Agricultural Policy's financial support schemes. Short rotation crops, however, are only some among many options for a future bioenergy supply. Tree species in longer rotation may also show interesting perspectives as energy crops. Crops in short or long rotation exhibit different characteristics in terms of flexibility regarding crop renewal, flexibility at harvest, storability, productivity and growth pattern. Combining the characteristics of different crops may prove beneficial in the development of a secure and productive bioenergy supply.

\section{Variability and inconsistencies in biomass potential studies}

Studies on biomass/bioenergy resources apply different methodologies, different definitions of resource potential, different geographical scope and different assumptions regarding availability. The lack of methodological consensus leads to disagreement, i.e. different potentials among different studies as to how much biomass of various fractions is available for energy. Resource potentials are usually categorised as theoretical, technical, economical or sustainable with potential sub-grouping relating to the practical implementation of a given potential within a certain time frame. Theory suggests a ranking of potentials as:
Theoretical $>$ technical $>$ economic $>$ sustainable.

Comparing results from different assessments of the same biomass resource doesn't provide a clear picture of the above relation. Variability and methodological inconsistency seem to overrule the theory.

Data illustrated here (Figures 2 and 3) represent the technical potential of biomass for energy. 'Technical potential' can be defined as "the fraction of the theoretical potential, which is available under the regarded techno-structural framework conditions and with the current technological possibilities. Spatial confinements due to competitions with other land uses as well as ecological and other non-technical constraints are also taken into account" [64]. The term 'technical potential' is not used unambiguously in literature $[28,58]$ but the above definition covers most applications.

2Böttcher et al. [39] report theoretical and technical potentials of agricultural residues and find the theoretical potential to $2.7 \mathrm{EJyr}^{-1}$ and the technical potential to $0.8 \mathrm{EJyr}^{-1}$. Böttcher et al. [39] also show for forestry a theoretical potential of wood residues of $5.2 \mathrm{EJyr}^{-1}$ and a technical potential of $3.3 \mathrm{EJyr}^{-1}$. Correspondingly, Asikainen et al. [59] find a theoretical potential of forest energy to $7.1 \mathrm{EJyr}^{-1}$ and technical $1.7 \mathrm{EJyr}^{-1}$. Mantau et al. [60] show technical to theoretical potential relations of forest biomass in 2010 of 6.5:11.1 and in 2030 of 6.4:10.9. A significant component in the difference between theoretical and technical potential is the omission of stump harvesting. While there is agreement that the technical potential is much lower than the theoretical potential, disagreement prevail on the fraction by which technical potential make up the theoretical potential. Here we show fractions between $24 \%$ and $63 \%$.

Some references report sustainable potentials of forest biomass. Hetch [46] show for the EU27 a current potential of 1.4 EJyr ${ }^{-1}$, Fischer et al. [16] find for geographical Europe excluding former Soviet Union the current potential to 11.3 $\mathrm{EJyr}^{-1}$ rising to $14.2-18.1 \mathrm{EJyr}^{-1}$ in 2050. EEA [42] finds for the EU25 a current potential of $1.8 \mathrm{EJyr}^{-1}$ decreasing to 1.6 $\mathrm{EJyr}^{-1}$ in 2030. Although the geographical coverage isn't identical, the above data illustrate the level of variation between individual assessments even though the scope (sustainable bioenergy potentials from forest biomass) is the same.

\section{Geographical scope}

Geographical scope differs among studies and impedes direct comparison among them. Data presented in Figures 2, 3 and 4 represents EU25, EU27 or EU27 and Switzerland. Johansson et al. [47] estimate for OECD Europe agricultural residue potential of $1.41 \mathrm{EJyr}^{-1}$ in 2025 and 2050 and a forest + forest industry potential of $1.69 \mathrm{EJyr}^{-1}$ in 2025 and $1.68 \mathrm{EJyr}^{-1}$ in 2050. Also for OECD Europe Bauen et al. [38] find a crop residue potential of $3.4 \mathrm{EJyr}^{-1}$ and a forest residue potential of $4.8 \mathrm{EJyr}^{-1}$ in 2020. Hall et al. [45] also 
look at OECD Europe and find a 2020 residue potential of $2.3 \mathrm{EJyr}^{-1}$ and energy crops of $6.7 \mathrm{EJyr}^{-1}$. Estimates for OECD Europe do not deviate unequivocally from EU27 estimates. Bauen et al's estimates on agricultural and forest residues exceed the ranges plotted in Figure 2. Energy crop potentials as estimated by Hall et al. exceed the plotted ranges. de Witt et al. [54] estimate the biomass for energy potential for various resources for the EU27 and Norway, Switzerland and Ukraine. Here dedicated energy crops and agricultural residues exceed the plotted ranges, whereas forest biomass falls within the range. The inclusion of a country with a large agricultural sector may be one of the reasons for the comparatively high estimates of resources from agricultural lands. Rettenmaier et al. [64] have made an attempt to calibrate a range of recent bioenergy resource assessments regarding Europe to EU27 level to improve comparability across individual assessments.

\section{Sustainability constraints}

It is widely acknowledged that ecological concern and competing uses constrain the use of the agricultural residue resource and all studies apply an availability factor to the total residue production. There is, however, no general agreement among studies on the size of these constraints and thus the factors used. Literature reviewed here apply availability factors of $25 \%$ [30,41], 30\% [39,50,56], 40-50\% [49] and $50 \%[44,54]$. A number of studies do not specify what availability factor is used $[16,18,42,53]$. There is no significant correlation between the availability factor used and the residue potential reported (data not shown). Other literature presents availability factors ranging from zero [65] to $40-50 \%$ [66] to 60\% [67]. Ecological availability of agricultural residues cannot be determined with general validity [68]. Positive correlations between carbon content in soil and soil productivity have been found for various crops in different regions [69-72]. It is shown that differences in crop yield induced by differences in soil organic carbon content in many cases can be overcome by appropriate supply of mineral fertilisers [73,74].

Matau et al. [60] quantify the impact of environmental constraints on the potential of various biomass fractions from forestry. The reduction in potential of logging residues due to environmental constraints vary across regions and fall for most parts of Europe between 33 and 50\%. However in some regions e.g. northern Scotland, the alpine region and northern Scandinavia it may reach $100 \%$. Nabuurs et al. [75] find that meeting European renewable energy targets may increase the harvesting pressure on European forests and lead to overharvesting in some regions specially around 2030-2040.

\section{Methodological challenges}

The scientific challenge, as we see it, is not that different biomass resource assessments return differing results.
Resource assessments are used to answer different questions, e.g. on the impact on energy production in general of enacting certain policies; on the availability of specific resources for specific purposes; or on the viability of shifting from one energy resource to another. Consequently, the answers differ. The challenge is rather the lack of reproducibility and transparency. Resource assessments aiming at the same question should preferably return comparable answers. In the framework of the Biomass Energy Europe project (www.eu-bee.org) European bioenergy potential studies have been analysed to develop a harmonised resource assessment methodology [64].

\section{Biomass demand}

National renewable energy action plans provide an estimate of domestic and imported biomass resources required to meet the targets of the EU energy strategy. These estimates are reported under different assumptions regarding conversion efficiency and in differing units hampering direct use of data. We calculate biomass demand on basis of national renewable energy projections [76] with the application of conversion efficiency multipliers based on [5,77] and the assumption that 11\% of European electricity generation is based on co-generation of heat and electricity [78]. We find that the amount of biomass required meeting the EU27 targets increase from $3.8 \mathrm{EJ}$ in 2005 to 10.0 EJ by 2020 (Figure 5). In 2009 the EU27 countries had a primary production of biomass and waste of 4,2 EJ [79]. The amount of biomass required in 2020 includes the use of $\sim 0.1 \mathrm{EJ}$ of traditional food crops, i.e. cereals and sugar beet for $1^{\text {st }}$ generation bioethanol and oil crops for biodiesel as well as $0.5 \mathrm{EJ}$ in countries outside EU27 as feedstock for liquid fuel. Heat and electricity production make up the lion's share in all years to 2020, but transportation increase from $5 \%$ of the biomass demand in 2005 to $18 \%$ in 2020 . In a longer perspective to 2050 or

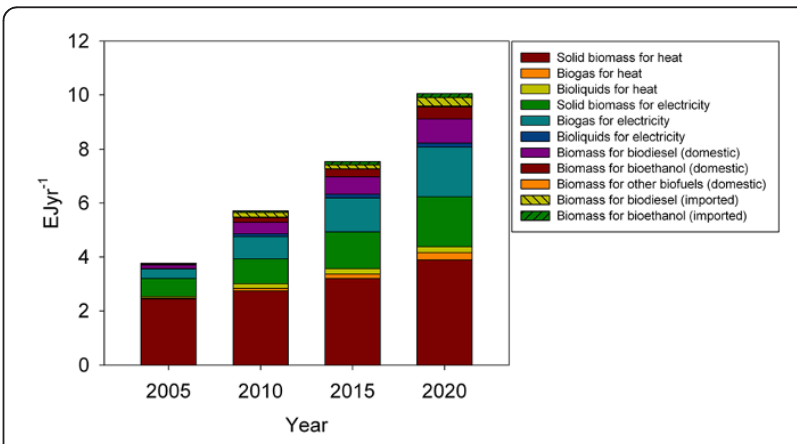

Figure 5 Estimated demand for biomass for energy in the EU27 countries based on national renewable energy projections [76] and reported conversion efficiencies [5,77]. 
2100 substantially more biomass must be expected to be converted to energy services in the EU27 countries to meet the long term targets of decarbonising the electricity and transport sector [2].

Demand for biomass for other purposes besides energy has an impact on the bioenergy potential. Exploring four different development scenarios Hoogwijk et al. [23] find that the meat demand has an impact on area available for energy crops. In their high population growth and high meat consumption scenario (A2) they show close to three times the agricultural area for food production than their low population growth and low meat consumption scenario (B1) reducing the European energy crop potential on abandoned agricultural land from 24 to $21 \mathrm{EJyr}^{-1}$ in year 2100 . On a global scale Yamamoto et al. [80] finds that high demand for meat reduces the global energy crop potential from $150 \mathrm{EJyr}^{-1}$ (reference case) to $78 \mathrm{EJyr}^{-1}$ (high demand for animal food case), whereas the potential from food biomass residues increase from 160 to $186 \mathrm{EJyr}^{-1}$ for the same scenarios.

\section{Land use}

Bioenergy production may be increased through further mobilisation of existing resources, intensification of current production or expansion into 'new' land. The impact on GHG emissions from an expanded production of energy crops have been widely analysed, e.g. $[81,82]$. Delucchi $[83]$ reviews recent literature and methodologies. One main finding is that the conversion of forest, grasslands and wetlands to agriculture results in loss of carbon in soil and biomass. This is corroborated by Don et al. [84]. The type of biomass for energy grown on converted land also affects the carbon balance in soil and biomass. In general perennial species as sugar cane and Miscanthus are favourable to annual species as they sequester carbon in soil [85]. An option for reducing the impacts of bioenergy on land use may be to consider a more integrated approach to land use simultaneously producing energy and food on the same land [86,87].

Burney et al. [88] and Vlek et al. [89] find that in many cases increased agricultural production achieved through intensification is favourable to agricultural expansion in terms of GHG emissions. This conclusion, however, requires land liberated due to intensification are converted into forest of forest land being 'spared' from conversion.

Land use, land use change and (environmental) sustainability of energy crop production have become a major issue in European policy [90] on biomass for energy. As a result GHG emissions caused by land use change must now be included in meeting sustainability criteria set up by the European Parliament [1]. Land use change is highly dynamic and localised and the quantification of land use effects on the climate currently builds on a weak methodological foundation [91]. Models tend to be static and work on a national or regional geographical and not validated against local empirical data [84,91].

Ovando et al. [92] estimate the land required to produce energy crops in EU-25 based on a number of studies. 5-20 Mha is required in 2000-2010 rising to 25-45 Mha in 2100. The European Biomass Association estimates the current (2007-08) allocation of traditional food crops to energy purposes to 4 Mha and additional 85,000 ha to lignocellulosic crops [93]. While area availability is the ultimately limiting factor
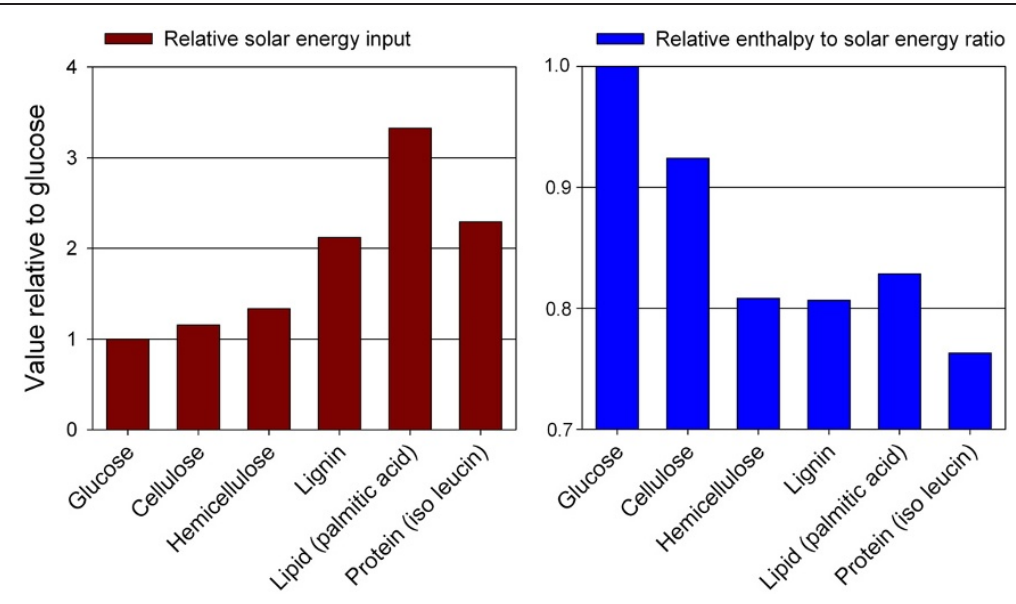

Figure 6 Solar radiation energy needed to the synthesis of individual plant components (left pane) and the relation between solar energy input and enthalpy of combustion of individual plant components (right pane). Values are relative to energy input and enthalpy to energy input ratio for glucose. Based on [96-98]. 
for expanded production of energy crops, limited access to water and nutrients may also constrain bioenergy potentials. Particularly nitrogen efficient crops are found among tree species and grasses [94,95].

\section{Component specificity}

Using biomass for energy is a way of harnessing solar energy. Biomass is a complex mixture composed primarily of more or less polymerised sugars, lipids, lignin, proteins and organic acids in varying proportions [96]. Complex components require more solar energy for synthesis than simple molecules and structures. Synthesis of lignin, lipids and proteins theoretically requires respectively 112, 233 and 129\% more solar energy input per unit of mass than the synthesis of starch (calculated from $[97,98]$ ) (Figure 6 left pane). These components also contain more chemically bound energy but the relation between energy content (enthalpy of combustion calculated from $[99,100]$ ) and required solar energy input show that, relatively speaking, the use of proteins for energy generation is a poorer exploitation of solar energy and thus land area, than the use of lignin, lipids and hemicellulose, which again is a poorer exploitation of solar energy than the use of cellulose (Figure 6 right pane).

Some conversion technologies have a degree of component specificity, while others do not. Thermochemical conversion destroys every component in biomass converting it to $\mathrm{CO}_{2}, \mathrm{CO}, \mathrm{H}_{2}, \mathrm{CH}_{4}, \mathrm{NO}_{\mathrm{X}}$ and water in various amounts [101]. Methane fermentation technologies exhibit higher specificity. Lignin is not converted, $34-92 \%$ of the proteins are hydrolysed and fermented depending on various conditions [102], $70-95 \%$ of lipids [103,104], $65-70 \%$ of polymerised sugars [103] and 95\% of sugar oligomers are destroyed [103]. In ethanol fermentation only simple sugars are converted to ethanol and $\mathrm{CO}_{2}$. Conversion rates of polymerised sugars depend on the efficiency of the preceding hydrolysis. Lignin and protein are not destroyed during fermentation.

The higher component specificity of biochemical and catalytic-chemical conversion has the attraction over thermochemical conversion of conserving to some degree the components requiring more solar energy for biosynthesis. Preserving the solar energy intensive components to uses other than energy may reduce the impact on land use from bioenergy production. Proteins found in the by-product from grain based ethanol production may serve as valuable feed product [105] but may also be further processed to higher value products and provide an even higher displacement of fossil fuels [106]. In a biorefinery context the lignin residue from processing lignocellulosic biomass is considered a valuable energy source for process heat and electricity. Industrial processing of lignin to aromatics as phenol, styrene or toluene may, however, also provide higher abatement of fossil GHG emissions [106].

\section{Conclusions and outlook}

The demand for biomass for energy in the European Union will increase from the current $5.7 \mathrm{EJ} \mathrm{yr}^{-1}$ to $10.0 \mathrm{EJyr}^{-1}$ by 2020. Dedicated energy crops grown on liberated agricultural land or marginal lands are expected to be able to meet the major part of the increasing biomass demand. Residues from agriculture and forestry are not expected to increase significantly in the future. The demand for biomass for energy will probably increase also beyond 2020 and not only in Europe. This calls for further technology development and increased focus on technology integration to meet the grand challenge of a decarbonised energy supply.

Further development of harmonised and transparent assessment methodologies is required to improve applicability and reproducibility of such assessments.

To meet future needs for biomass, not only for energy, also for food, feed and materials emphasis must be put on increasing the production of biomass per unit of land and exploring the potentials in new biomass sources to reduce the pressure on native and protected eco systems.

Further focus on optimised utilisation of individual plant components in biomass with a link to the component specificity of different conversion technologies could improve the utility gained from biomass and bioenergy and reduce negative impacts on land use.

\section{Endnotes}

${ }^{a}$ The current (2012) 27 member countries of the European Union: Austria, Belgium, Bulgaria, Cyprus, Czech Rep., Denmark, Estonia, Finland, France, Germany, Greece, Hungary, Ireland, Italy, Latvia, Lithuania, Luxembourg, Malta, Netherlands, Poland, Portugal, Romania, Slovakia, Slovenia, Spain, Sweden, United Kingdom.

${ }^{\mathrm{b}} \mathrm{EU} 25=$ Members of the European Union as of 2004: EU27 minus Bulgaria and Romania.

\section{Competing interests}

The authors declare no competing interests.

\section{Author's contributions}

NSB and CF conceptualised the manuscript. NSB was responsible for literature review, data acquisition and analysis and initial writing. CF contributed with review and editing. NSB and CF read and approved the final manuscript.

\section{Acknowledgements}

This review is made in conjunction with the CEESA project (www.ceesa.dk) financially supported by the Danish Council for Strategic Research.

Received: 09 November 2011 Accepted: 30 April 2012

Published: 30 April 2012

\section{References}

1. European Parliament and the Council: Directive 2009/28/EC of the European Parliament and of the Council of 23 April 2009 on the promotion of the use of 
energy from renewable sources and amending and subsequently repealing Directives 2001/77/EC and 2003/30/EC. Brussels, BE: The European Parliament and the Council; 2009.

2. Commission E: Energy 2020 A strategy for competitive, sustainable and secure energy. Brussels, BE: European Commission; 2010.

3. Congress US: Energy Policy Act of 2005. Washington DC, US: U.S. Congress: 2005.

4. Congress US: Energy Independence and Security Act of 2007. Washington DC, US: U.S. Congress; 2007.

5. Turkenburg WC, Beurskens J, Faaij A, Fraenkel P, Fridleifsson I, Lysen E, Mills D, Moreira JR, Nilsson LJ, Schaap A, Sinke WC: Renewable Energy Technologies. In World Energy Assessment. Edited by Goldemberg J. New York, NY: United Nations Development Programme; 2000.

6. da Costa ACA, Junior NP, Aranda DAG: The situation of biofuels in Brazil: new generation technologies. Renew Sustain Energ Rev 2010, 14:3041-3049.

7. Ministério da Agricultura Pecuária e Abastecimento: Produção Brasileira de Etanol. Brasilia, BR: Ministério da Agricultura Pecuária e Abastecimento; 2011.

8. Ministério da Agricultura Pecuária e Abastecimento: Balancio nacional da cana-de-acucar e agroenergia. Brasilia, BR: Ministério da Agricultura, Pecuária e Abastecimento; 2007.

9. Edenhofer O, Pichs-Madruga R, Sokona Y, Seyboth K, Arvizu D, Bruckner T, Christensen J, Devernay J-M, Faaij A, Fischedick M, et al: Summary for Policy Makers. In IPCC Special Report on Renewable Energy Sources and Climate Change Mitigation. Edited by Edenhofer $\mathrm{O}$, Pichs-Madruga R, Sokona Y, Seyboth K, Matschoss P, Kadner S, Zwickel T, Eickemeier P, Hansen G, Schlöme S, Stechow CV. Cambridge, United Kingdom and New York, NY, USA: Cambridge University Press; 2011

10. Campbell JE, Lobell DB, Genova RC, Field CB: The global potential of bioenergy on abandoned agriculture lands. Environ Sci Technol 2008 42:5791-5794.

11. de Vries BJM, van Vuuren DP, Hoogwijk MM: Renewable energy sources: their global potential for the first-half of the 21st century at a global level: a integrated approach. Energy Policy 2007, 35:2590-2610

12. Doornbosch R, Steenblik R: Biofuels: Is the cure worse than the disease? Paris, France: Organisation for Economic Co-operation and Development; 2007.

13. Dornburg V, Faaij A, Verweij P, Langeveld H, Gvd V, Wester F, Hv K, Kv D, Meeusen M, Banse M, et al: Assessment of global biomass potentials and their links to food, water, biodiversity, energy demand and economy. Utrecht, NL: Utrecht University; 2008.

14. Dornburg V, van Vuuren D, van de Ven G, Langeveld H, Meeusen M, Banse M, van Oorschot M, Ros J, Jan van den Born G, Aiking H, et al: Bioenergy revisited: key factors in global potentials of bioenergy. Energ Environ Sci 2010, 3:258-267

15. Field C, Campbell J, Lobell D: Biomass energy: the scale of the potential resource. Trends Ecol Evol 2008, 23:65-72.

16. Fischer G, Schrattenholzer L: Global bioenergy potentials through 2050. Biomass Bioenergy 2001, 20:151-159.

17. Fujino J, Yamaji K, Yamamoto H: Biomass-Balance Table for evaluating bioenergy resources. Appl Energ 1999, 63:75-89.

18. Haberl H, Beringer T, Bhattacharya SC, Erb K-H, Hoogwijk M: The global technical potential of bio-energy in 2050 considering sustainability constraints. Curr Opin Environ Sustainability 2010, 2:394-403.

19. Hall DO: Biomass energy. Energy Policy 1991, 19:711-737.

20. Hall DO, Rosillo-Calle F, Williams RH, Woods J: Biomass for energy: Supply prospects. In Renewable Energy: Sources for Fuels and Electricity. Edited by Johansson TB, Kelly H, Reddy AKN, Williams RH. Washington DC, US: Island Press; 1993.

21. Henry RJ: Evaluation of plant biomass resources available for replacement of fossil oil. Plant Biotechnol J 2010, 8:288-293.

22. Hoogwijk M: Exploration of the ranges of the global potential of biomass for energy. Biomass and Bioenergy 2003, 25:119-133

23. Hoogwijk M, Faaij A, Eickhout B, Devries B, Turkenburg W: Potential of biomass energy out to 2100 , for four IPCC SRES land-use scenarios. Biomass Bioenergy 2005, 29:225-257.

24. Johnston M, Holloway T: A Global Comparison of National Biodiese Production Potentials. Environ Sci Technol 2007, 41:7967-7973.
25. Moreira JR: Global Biomass Energy Potential. Mitig Adapt Strateg Glob Chang 2006, 11:313-333.

26. Resch G, Held A, Faber T, Panzer C, Toro F, Haas R: Potentials and prospects for renewable energies at global scale. Energy Policy 2008, 36:4048-4056

27. Rogner H, Barthel F, Cabrera M, Faaij A, Giroux M, Hall DO, Kagramanian V Kononov S, Lefevre T, Moreira R, et al: Energy Resources. In World Energy Assessment: Energy and the challenge of sustainability. Edited by Goldemberg J. New York NY, US: United Nations Development Programme; 2000.

28. Schubert R, Schellnhuber HJ, Buchmann N, Epiney A, Grießhammer R, Kulessa M, Messner D, Rahmstorf S, Schmid J: Future Bioenergy and Sustainable Land Use. London, UK: Earthscan; 2009.

29. Sims REH, Schock RN, Adegbululgbe A, Fenhann J, Konstantinaviciute I, Moomaw W, Nimir HB, Schlamadinger B, Torres-Martínez J, Turner C, et al: Energy supply. In Climate Change 2007: Mitigation Contribution of Working Group III to the Fourth Assessment Report of the Intergovernmental Panel on Climate Change. Edited by Metz B, Davidson OR, Bosch PR, Dave R, Meyer LA. Cambridge, United Kingdom and New York, NY, USA: Cambridge University Press; 2007.

30. Smeets E, Faaij A, Lewandowski I, Turkenburg W: A bottom-up assessment and review of global bio-energy potentials to 2050. Prog Energy Combust Sci 2007, 33:56-106.

31. Smeets EMW, Faaij APC: Bioenergy potentials from forestry in 2050. Clim Chang 2007, 81:353-390.

32. Smil V: Crop Residues: agriculture's largest harvest. Bioscience 1999, 49:10.

33. Swisher J, Wilson D: Renewable energy potentials. Energy 1993, 18:437459.

34. Thrän D, Seidenberger T, Zeddies J, Offermann R: Global biomass potentials - Resources, drivers and scenario results. Energ Sustain Dev 2010, 14:200-205.

35. van Vuuren DP, van Vliet J, Stehfest E: Future bio-energy potential under various natural constraints. Energy Policy 2009, 37:4220-4230.

36. World Energy Council: 2010 Survey of Energy Resources. London, UK: World Energy Council; 2010.

37. Alakangas E, Heikkinen A, Lensu T, Vesterinen P: Biomass fuel trade in Europe Jyväskylä, Finland: VTT; 2007.

38. Bauen A, Woods J, Hailes R: Bioelectricity Vision: Achieving 15\% of Electricity from Biomass in OECD Countries by 2020. London, UK: Imperial College London, Centre for Energy Policy and Technology and E4tech (UK) Ltd; 2004

39. Böttcher H, Dees M, Fritz SM, Goltsev V, Gunia K, Huck I, Lindner M, Paappanen T, Pekkanen JM, Ramos CIS, et al: Biomass Energy Europe: Illustration Case for Europe. Laxenburg, Austria: International Institute for Applied Systems Analysis; 2010.

40. de Wit M, Faaij APC, Fischer G, Prieler S, Velthuizen HT: Biomass Resources Potential and Related Costs. The Cost-Supply Potential of Biomass Resources in the EU-27, Switzerland, Norway and the Ukraine. Utrecht, NL and Laxenburg, AT: Copernicus Institute, Utrecht University and the International Institute of Applied Systems Analysis; 2008

41. Ericsson K, Nilsson L: Assessment of the potential biomass supply in Europe using a resource-focused approach. Biomass Bioenergy 2006, 30:115.

42. European Environment Agency: How much bioenergy can Europe produce without harming the environment? Copenhagen: European Environment Agency; 2006

43. Fischer $G$, Hiznyik E, Prieler S, van Velthuizen HT: Assessment of biomass potentials for biofuel feedstock production in Europe: Methodology and results. Laxenburg, Austria: International Institute for Applied Systems Analysis; 2007.

44. Fischer $G$, Prieler $S$, van Velthuizen $H$, Berndes $G$, Faaij $A$, Londo M, de Wit M: Biofuel production potentials in Europe: sustainable use of cultivated land and pastures, Part II: Land use scenarios. Biomass Bioenergy 2010, 34:173-187.

45. Hall DO, House J: Biomass energy in Western Europe to 2050. Land Use Policy 1995, 12:37-48.

46. Hetsch S: Potential Sustainable Wood Supply in Europe. Geneva: United Nations Economic Commission for Europe/Food and Agriculture Organization of the United Nations; 2009.

47. Johansson TB, Kelly H, Reddy AKN, Williams RH: Renewable fuels and electricity for a growing world economy. In Renewable Energy - Sources for fuels and electricity. Edited by Johansson TB, Kelly H, Reddy AKN, Williams RH. Washington DC, US: Island Press; 1993:1-72. 
48. Nielsen JBH, Oleskowicz-Popiel P, Seadi TA: Energy crop potentials for bioenergy in EU-27. In 15th European Biomass Conference \& Exhibition: From Research to Market Deployment; 7-11 May, Berlin, Germany. 2007:17. ETA Florence.

49. Scarlat N, Martinov M, Dallemand J-F: Assessment of the availability of agricultural crop residues in the European Union: potential and limitations for bioenergy use. Waste Manage 2010, 30:1889-1897.

50. Siemons R, Vis M, van den Berg D, McChesney I, Whiteley M, Nikolaou N: Bio-energy's Role in the EU Energy Market: A View of Developments until 2020 Enshcede, the Netherlands: Biomass Technology Group (BTG), Energy for Sustainable Development, Centre for Renewable energy (CRES); 2004.

51. Skytte K, Meibom P, Henriksen TC: Electricity from biomass in the European union-With or without biomass import. Biomass Bioenergy 2006, 30:385-392.

52. van Dam J, Faaij A, Lewandowski I, Fischer G: Biomass production potentials in Central and Eastern Europe under different scenarios. Biomass Bioenergy 2007, 31:345-366.

53. RENEW: Renewable fuels for advanced powertrains. Ganderkesee, GE: SYNCOM Forschungs- und Entwicklungsberatung; 2008

54. de Wit M, Faaij A: European biomass resource potential and costs. Biomass Bioenergy 2010, 34:188-202.

55. Fischer $G$, Prieler $S$, van Velthuizen $H$, Lensink SM, Londo $M$, de Wit $M$ : Biofuel production potentials in Europe: Sustainable use of cultivated land and pastures. Part I: Land productivity potentials. Biomass and Bioenergy 2010, 34:159-172

56. Panoutsou C, Eleftheriadis J, Nikolaou A: Biomass supply in EU27 from 2010 to 2030. Energy Policy 2009, 37:5675-5686.

57. Berndes $\mathrm{G}$ : The contribution of biomass in the future global energy supply: a review of 17 studies. Biomass Bioenergy 2003, 25:1-28.

58. Offermann R, Seidenberger T, Thrän D, Kaltschmitt M, Zinoviev S, Miertus S: Assessment of global bioenergy potentials. Mitig Adapt Strateg Glob Chang 2011, 16:103-115

59. Asikainen A, Liiri H, Peltola S, Karjalainen T, Laitila J: Forest Energy Potential in Europe (EU27). Helsinki, Finland: Finnish Forest Research Institute; 2008.

60. Mantau U, Saal U, Prins K, Steierer F, Lindner M, Verkerk H, Eggers J, Leek N, Oldenburger J, Asikainen A, Anttila P: EUwood-Real potential for changes in growth and use of EU forests. Hamburg, Germany: University of Hamburg: 2010.

61. Krasuska E, Cadórniga C, Tenorio JL, Testa G, Scordia D: Potential land availability for energy crops production in Europe. Biofuels, Bioprod Biorefin 2010, 4:658-673.

62. Eurostat: Farmland: Number of farms and areas by size of farm (UAA) and region. edn. Brussels, BE: Eurostat; 2011.

63. FAOSTAT: ResourceSTAT. Rome, IT: Food and Agriculture Organisation of the United Nations; 2011

64. Rettenmaier N, Schorb A, Köppen S, Berndes G, Christou M, Dees M, Domac J, Eleftheriadis I, Goltsev V, Kajba D, et al: Status of Biomass Resource Assessments, Version 3. Freiburg, Germany: University of Freiburg, Department of Remote sensing and Landscape Information Systems; 2010.

65. Patzek TW: Thermodynamics of the Corn-Ethanol Biofuel Cycle. Crit Rev Plant Sci 2004, 23:519-567.

66. Kadam KL, McMillan JD: Availability of corn stover as a sustainable feedstock for bioethanol production. Bioresour Technol 2003 $88: 17-25$

67. Kätterer T, Andrén O, Persson J: The impact of altered management on long-term agricultural soil carbon stocks - a Swedish case study. Nutr Cycl Agroecosyst 2004, 70:179-187.

68. Wilhelm WW, Johnson JMF, Hatfield JL, Voorhees WB, Linden DR: Crop and Soil Productivity Response to Corn Residue Removal. Agron J 2004, 96:117

69. Bauer A, Black AL: Quantification of the Effect of Soil Organic Matter Content on Soil Productivity. Soil Sci Soc Am J 1994, 58:185-193.

70. Diaz-Zorita M, Buschiazzo DE, Peinemann N: Soil Organic Matter and Wheat Productivity in the Semiarid Argentine Pampas. Agron J 1999, 91:4

71. Janzen HH, Schaalje GB: Barley response to nitrogen and non-nutritional benefits of legume green manure. Plant Soil 1992, 142:19-30.

72. Quiroga A, Funaro D, Noellemeyer E, Peinemann N: Barley yield response to soil organic matter and texture in the Pampas of Argentina. Soil Tillage Res 2006, 90:63-68.

73. Edmeades DC: The long-term effects of manures and fertilisers on soil productivity and quality: a review. Nutr Cycl Agroecosyst 2003, 66:165-180
74. Loveland P, Webb J: Is there a critical level of organic matter in the agricultural soils of temperate regions: a review. Soil Tillage Res 2003 70:1-18.

75. Nabuurs G, Pussinen A, van Brusselen J, Schelhaas M: Future harvesting pressure on European forests. Eur J For Res 2007, 126:391-400.

76. Beurskens LWM, Hekkenberg M: Renewable Energy Projections as Published in the National Renewable Energy Action Plans of the European Member States. Petten, NL. Energy Research Centre of the Netherlands and European Environment Agency; 2011

77. International Energy Agency: Energy Technology Perspectives 2008. Paris, FR: International Energy Agency; 2008.

78. Eurostat: Combined heat and power generation: Percentage of gross electricity generation. 11-03-2011 edn. Brussels, BE: Eurostat; 2011.

79. Eurostat: Renewable energy primary production: biomass, hydro, geothermal, wind and solar energy. 11-03-2011 edn. Brussels, BE: Eurostat; 2011.

80. Yamamoto $H$, Yamaji K, Fujino J: Scenario analysis of bioenergy resources and $\mathrm{CO} 2$ emissions with a global land use and energy model. Appl Energ 2000, 66:325-337.

81. Fargione J, Hill J, Tilman D, Polasky S, Hawthorne P: Land Clearing and the Biofuel Carbon Debt. Science 2008, 319:1235-1238.

82. Searchinger $T$, Heimlich $R$, Houghton RA, Dong F, Elobeid A, Fabiosa J, Tokgoz S, Hayes D, Yu TH: Use of U. S. Croplands for Biofuels Increases Greenhouse Gases Through Emissions from Land-Use Change. Science 2008, 319:1238-1240.

83. Delucchi M: A conceptual framework for estimating the climate impacts of land-use change due to energy crop programs. Biomass Bioenergy 2011, 35:2337-2360.

84. Don A, Osborne B, Hastings A, Skiba U, Carter MS, Drewer J, Flessa H, Freibauer A, Hyvönen $\mathrm{N}$, Jones MB, et al: Land-use change to bioenergy production in Europe: implications for the greenhouse gas balance and soil carbon. GCB Bioenergy 2011.

85. Somerville C, Youngs H, Taylor C, Davis SC, Long SP: Feedstocks for Lignocellulosic Biofuels. Science 2010, 329:790-792.

86. Ceotto E, Candilo M: Sustainable Bioenergy Production, Land and Nitrogen Use. In Biodiversity, Biofuels, Agroforestry and Conservation Agriculture. Volume 5. Edited by Lichtfouse E. Dordrecht, NL: Springer; 2011:101-122. Sustainable Agriculture Reviews.

87. Porter J, Costanza R, Sandhu H, Sigsgaard L, Wratten S: The value of producing food, energy, and ecosystem services within an agro-ecosystem. AMBIO: J Hum Environ 2009, 38:186-193.

88. Burney JA, Davis SJ, Lobell DB: Greenhouse gas mitigation by agricultural intensification. Proc Natl Acad Sci 2010, 107:12052-12057.

89. Vlek P, Rodríguez-Kuhl G, Sommer R: Energy Use and $\mathrm{CO}_{2}$ Production in Tropical Agriculture and Means and Strategies for Reduction or Mitigation. Environ Dev Sustain 2004, 6:213-233.

90. Cockerill S, Martin C: Are biofuels sustainable? The EU perspective. Biotechnology for Biofuels 2008, 1:9.

91. Dale VH, Kline KL, Wright LL, Perlack RD, Downing M, Graham RL: Interactions among bioenergy feedstock choices, landscape dynamics, and land use. Ecol App/ 2011, 21:1039-1054.

92. Ovando P, Caparrós A: Land use and carbon mitigation in Europe: a survey of the potentials of different alternatives. Energy Policy 2009, 37:992-1003.

93. European Biomass Association: Biomass statistics. Brussels, BE: European Biomass Association; 2011.

94. Miller SA: Minimizing Land Use and Nitrogen Intensity of Bioenergy. Environ Sci Technol 2010, 44:3932-3939.

95. Tilman D, Hill J, Lehman C: Carbon-Negative Biofuels from Low-Input High-Diversity Grassland Biomass. Science 2006, 314:1598-1600

96. Hay RKM, Porter JR: The physiology of crop yield. Oxford, UK: Blackwell Publishing; 2006

97. Penning de Vries FWT, Brunsting AHM, Van Laar HH: Products, requirements and efficiency of biosynthesis a quantitative approach. J Theor Biol 1974, 45:339-377.

98. Zhu X-G, Long SP, Ort DR: Improving photosynthetic efficiency for greater yield. Annu Rev Plant Biol 2010, 61:235-261.

99. Linstrom PJ, Mallard WG (Eds.): NIST Chemistry WebBook: NIST Standard Reference Database Number 69. Gaithersburg MD: National Institute of Standards and Technology; 2011. 
100. Wooley RJ, Putsche V: Development of an ASPEN PLUS Physical Property Database for Biofuels Components. Golden CO, US: National Renewable Energy Laboratory; 1996.

101. Bridgwater AV: Renewable fuels and chemicals by thermal processing of biomass. Chem Eng J 2003, 91:87-102.

102. Breure AM, Mooijman KA, Andel JG: Protein degradation in anaerobic digestion: influence of volatile fatty acids and carbohydrates on hydrolysis and acidogenic fermentation of gelatin. Appl Microbiol Biotechnol 1986, 24:426-431.

103. Jørgensen PJ: Biogas - grøn energi. Århus, Denmark: University of Aarhus: 2009.

104. Angelidaki I, Ellegaard L, Ahring BK: A comprehensive model of anaerobic bioconversion of complex substrates to biogas. Biotechnol Bioeng 1999, 63:363-372

105. Bentsen NS, Thorsen BJ, Felby C: Energy, feed and land-use balances of refining winter wheat to ethanol. Biofuels, Bioprod Biorefin 2009, 3:521-533.

106. Brehmer B, Boom RM, Sanders J: Maximum fossil fuel feedstock replacement potential of petrochemicals via biorefineries. Chem Eng Res Des 2009, 87:1103-1119.

doi:10.1186/1754-6834-5-25

Cite this article as: Bentsen and Felby: Biomass for energy in the European Union - a review of bioenergy resource assessments.

Biotechnology for Biofuels 2012 5:25.

\section{Submit your next manuscript to BioMed Central and take full advantage of:}

- Convenient online submission

- Thorough peer review

- No space constraints or color figure charges

- Immediate publication on acceptance

- Inclusion in PubMed, CAS, Scopus and Google Scholar

- Research which is freely available for redistribution 